\title{
Az Eurotransplant-csatlakozás első öt éve Magyarországon
}

\author{
Langer Róbert dr.
}

Ordensklinikum Linz, Krankenhaus der Elisabethinen, Chirurgie, Linz, Austria

\begin{abstract}
Az öt éve történt Eurotransplant-csatlakozás tanulságait vizsgálja a szerző a magyarországi szervátültetések több mint fél évszázados történetén keresztül. A fokozatos fejlődés eredményezte azt a helyzetet, melynek során ma európai mércével mérhető transzplantációs aktivitást jegyezhetünk. A csatlakozás előtti állapothoz képest körülbelül 40\%-kal több átültetés történik hazánkban. Elsőként jelentősen megemelkedett az élődonoros veseátültetések száma, majd ezt követte az agyhalottakból származó szervek transzplantációinak szignifikáns emelkedése a vese, a szív, a hasnyálmirigy, majd a máj és végül a tüdő vonatkozásában is. Az úgynevezett 'multiorgan' (többszervi) donorok aránya a korábbi 40\%-ról 70\% fölé emelkedett. Megnyugtató megoldás született a sürgősségi szervátültetések, a gyermektranszplantációk és az immunizált betegek vonatkozásában is, akik az Eurotransplant-csatlakozás nélkül reménytelen helyzetben volnának, így viszont minden magyar végstádiumú szervelégtelenségben szenvedő beteg ugyanolyan eséllyel kaphat adott esetben életmentő szervet, mint a korábban szerencsésebb helyzetben lévő nyugat-európai társaik.

Orv Hetil. 2018; 159(42): 1695-1699.
\end{abstract}

Kulcsszavak: szervtranszplantáció, szervdonáció, Eurotransplant, Magyarország

\section{The first five years of Hungary's Eurotransplant membership}

The author concludes lessons learned from Hungary joining Eurotransplant five years ago through the more than half a century history of the Hungarian organ transplantation. The result of the stepwise evolution is that today's transplantation activity can be measured by a European benchmark. In comparison to the era before the membership, there are $40 \%$ more transplantations in the country. First the numbers of the living donor kidney transplantations significantly raised, followed by the organs transplanted from brain-dead donors: kidney, heart, pancreas, then liver and finally also lung. The ratio of the multiorgan donors changed from about $40 \%$ to more than $70 \%$. A reassuring solution was found for the high urgent cases, for the paediatric transplants and for the highly immunized patients, who would have been in a desperate situation without Eurotransplant, but now every Hungarian end-stage organ failure patient has similar chances for getting a potential life-saving organ as their former luckier West-European counterparts.

Keywords: organ transplantation, organ donation, Eurotransplant, Hungary

Langer R. [The first five years of Hungary's Eurotransplant membership]. Orv Hetil. 2018; 159(42): 1695-1699.

(Beérkezett: 2018. június 27.; elfogadva: 2018. július 12.)

\section{Rövidítések}

HLA = humán leukocytaantigén; OVSZ = Országos Vérellátó Szolgálat

\section{A hazai szervátültetés és az Eurotransplant rövid története}

A magyarországi szervátültetés immáron közel hat évtizedes története 1962-ben Szegeden kezdődött, amikor Németh András élődonoros veseátültetést hajtott végre
[1]. A technikailag sikeres mútét recipiense megfelelő kezelés hiányában sajnos csak 79 nappal élte túl a mútétet, a donor azonban a mai napig kiváló egészségnek örvend. További kísérletek történtek mind Szegeden, mind később Miskolcon is, de egyik mútét sem hozott tartós túlélést jelentô eredményt [2]. Ez a kezdeti „hőskorszak" lezárult 1973-ban, amikortól Budapesten szervezett átültetési program indult Perner Ferenc vezetésével [3]; azóta fokozatosan emelkedő esetszámban történtek veseátülttetések a rendszerváltás utánig két centrumban, 
Budapesten és Szegeden. Ez a második korszak a debreceni (1991) és a pécsi (1993) centrum indulásával zárult.

Hazánkban 1992-ben történt az első szívátültetés (Szabó Zoltán), 2007-től aztán külön centrumban a gyermek-szívtranszplantáció is megindult; 1995-től van szervezett májátültetés (Perner Ferenc), 1998-tól pancreasátültetés (Kalmár Nagy Károly). Budapesten 2003tól egy 'pilot' (kísérleti) projekt keretében pancreasszigetsejt-átültetések történtek (Langer Róbert). Ebben a harmadik korszakban a magyar donorok is egyre nagyobb arányban váltak ezzel úgynevezett 'multiorgan' (többszervi) donorrá. Számos szerv nem került felhasználásra, ugyanakkor gyakorlatilag megoldatlan volt a sürgôs, életmentő átültetések (szív, máj), egyes gyermektranszplantációk és a hiperimmunizáltak helyzete. A szakmát nemzetközi szinten jól ismerők számára egyre világosabb lett, hogy áttörő megoldást csak az Eurotransplant-csatlakozás jelenthet [4].

50 évvel ezelőtt Jon van Rood holland immunológus arra a következtetésre jutott, hogy a vesetranszplantációk hatékonyságát úgy lehetne megnövelni, ha a recipiensek az egyes centrumok donorkínálatánál szélesebb lehetőségból meríthetnének. Több centrum közös várólistája esetén a jobb donor-recipiens egyezés révén már a rövid távú (1 éves túlélés), de minden bizonnyal a hosszabb távú túlélés is jelentősen javulhatna. Megszületett egy határokon átívelő együttmúködés gondolata. Tekintettel arra, hogy ekkor még országos szervezetek nem voltak, csak egymással igen szorosan tudományos szinten együttmúködő centrumok, valójában nem országok, hanem centrumok csatlakoztak a kezdeményezéshez. Akkoriban még csak kevés centrum múködött, vezetőik jól ismerték egymást, a mindenki számára előnyös együttmúködés gondolata gyorsan elfogadottá vált. Van Rood a leideni egyetemen dolgozott, így a központ ott alakult meg, és azóta is oda érkeznek a donorjelentések, illetve ott történik az egységes elvek szerinti szervelosztás, azaz az allokáció. Az elosztás legfőbb elve nem változott az alapítás óta: a donorszervek nemzeti kincsnek tekintendők, tehát ha egy ország szervet exportál egy másiknak, akkor ugyanannyi szervet kell, hogy visszakapjon. Bonyolult pontrendszer alapján áll fel a lista egy adott donor esetén, melyben fontos elv az immunológiai egyezés a hat vizsgált humán leukocytaantigénre (HLA) vonatkozóan, de a várakozási idő, az életkor, adott esetben a méret és az említett egyensúly mind szerepet kapnak. A Benelux államok, Németország és Ausztria transzplantációs központjaihoz néhány évig a hetvenes évek elején Svájc is csatlakozott, majd kilépett. A szervek szállításának a logisztikai részletei gyorsan kialakultak, az eredmények igazolták a hipotézis sikerességét, az együttmúködés rutinná vált. A leideni központ számítógépes hátterét folyamatosan újították a megnövekedett igényekhez. A vesetranszplantációk számának növekedésével és a sikeres kooperáció tapasztalataival gazdagodva az egyre nagyobb számú extrarenalis szervtranszplantációval szinte automatikusan ezek allokációja is Leidenbe került. Így aztán az 1980-as évektől már a máj- és szívtranszplantációk területén jelentett jelentős előrelépést az Eurotransplant a tagországok számára. Később a hasnyálmirigy- és a tüdőallokáció is csatlakozott az allokációs rendszerhez [5]. Fontos megjegyezni, hogy az Eurotransplant nem az Európai Unió hivatalos szerve, hanem egy nonprofit alapítvány, mely jelenleg 8 uniós ország transzplantációs aktivitását hangolja össze.

\section{Intertransplant}

Ezzel párhuzamosan a „nyugati” kihívásra válaszul 1974-ben Prágában megalakult a szocialista országok hasonló szervezete, az Intertransplant. Az alapító tagok: Szovjetunió, NDK, Csehszlovákia, Magyarország, Lengyelország, Bulgária és Kuba. Érdekes, hogy Románia és Jugoszlávia hiányzik a névsorból, a magyarázat nyilván e két ország külön utas politikája. Amerikából 1971 karácsonyán egy vesét küldtek Hollandiába katonai repülőgépen, ez a vese aztán 17 évig múködött. Feltehetően erre válaszul Kubában beültettek egy Csehszlovákiából származó vesét, Lengyelországban pedig egy Kubából érkezőt. Kubával több szervcsere nem is történt, az Intertransplant inkább csak kirakat volt, valós előnyei nem voltak. Magyarország az Intertransplant utolsó 10 évében 517, magyar donortól származó szerv átültetése mellett kapott keletnémet területről 78 és Csehszlovákiából 10 vesét, illetve még két szovjet és egy Eurotransplant-szerv került felhasználásra. Cserébe 13 vesét küldtünk Csehszlovákiába, 8-at az NDK-ba és 6-ot Lengyelországba [6]. Meg kell említeni, hogy a prágai központ igen komoly számítógépes háttérrel rendelkezett, de a szervezettség meg sem közelítette az Eurotransplantét. Évente voltak hivatalos találkozók érdemi eredmények nélkül, a rendszerváltás kapcsán aztán megszűnt az Intertransplant.

Egyre szembeszökőbb lett ez a diszkrepancia a „nyugati” standarddal szemben. Az Eurotransplant-csatlakozás lehetősége először a rendszerváltás után merült fel, azonban akkor valóban nem volt rá igazán szükség: a két vesetranszplantációs központ ellátta az országot, a költségek nem álltak volna arányban a kapott szolgáltatással. De a helyzet gyorsan változott, mint azt a fentiekben elemeztük. A rendszerváltást követően a keletnémet terület automatikusan csatlakozott az Eurotransplantrégióhoz, majd számos nehézséget legyőzve Szlovénia és Horvátország is. Ezek a bővülések mindenhol a transzplantációk számának növekedését és színvonal-emelkedést hoztak, a legkorszerúbb nemzetközi standardok bevezetését eredményezték.

\section{Az új korszak kezdete}

2009-ben a Semmelweis Egyetem Transzplantációs és Sebészeti Klinikájának igazgatói állását e cikk szerzője nyerte el, és azonnal megkezdtem a tárgyalásokat az Eurotransplant elnökével, általános és orvos igazgatójával. 
Elmondták, hogy részükről megvolt a nyitottság, de sem a hivatalos politika (korábban 5 miniszterrel tárgyaltak), sem a szakma részérôl nem volt igazán fogadókészség. Tovább nehezítette a helyzetet, hogy a szerencsétlen történetû Hungarotransplant nevű szervezet anyagi csődje, illetve egy folyamatban lévő bírósági feljelentés miatt ők sem eróltették a további kapcsolatfelvételt.

Szerencsére a bizalmat sikerült helyreállítani, a bírósági feljelentés megszúnt, a Hungarotransplantot felszámolták, helyére az Országos Vérellátó Szolgálat Szervkoordinációs Irodája lépett jogutódként [7]. Elsőként azt az áldatlan állapotot szüntettük meg, amely a kivevőteamek és a szervek szállítását jellemezte. Az Országos Mentőszolgálat bár mindig készséges volt, de amennyiben például a pécsi team egy miskolci pancreast távolított el, négy megyehatárt kellett átlépniük, tehát öt különböző mentőautóba kellett átszállniuk, majd a visszaúton ugyanez még egyszer. A 'multiorgan' donorok esetén még tovább bonyolódott a helyzet. Végül sikerült a minisztériummal és az OVSZ-szel egyezségre jutni: a minisztérium vásárolt öt új mentőautót, melyeket az OVSZ üzemeltetett, így megnyugtató módon rendeződött a szervkivevő teamek, a donorvérek és a szervek szállítása, célba juttatása.

A Magyar Transzplantációs Társaság újjáalakult elnöksége egyhangúan döntött arról, hogy a cél az Eurotransplant-tagság, és megbízta Langer professzort ennek lebonyolításával. A 2010-ben újjászervezett Egészségügyi Államtitkárság vezetője, Szócska Miklós pedig szintén támogatta az elképzelést, így aztán a szakmával történt egyeztetést követően 2010 decemberében sajtótájékoztatón történt a bejelentés, miszerint a szervtranszplantáció fejlődése érdekében a következő pontoknak kell megvalósulniuk: 1) a várólisták feltöltése, 2) a szakma és a laikus közönség tájékoztatása a transzplantációról, 3 ) a szervdonáció fejlesztése, 4) a tüdőtranszplantáció hazahozatala Bécsből, 5) csatlakozás az Eurotransplanthoz [8].

Hivatalos tárgyalódelegáció került kijelölésre, melyet Langer professzor javaslatára Perner professzor vezetett. Langer professzor mellett Kóbori professzor mint a Magyar Transzplantációs Társaság elnöke és Mihály Sándor mint az OVSZ Szervkoordinációs Iroda vezetője képviselték a szakmát; a tárgyalások egyes szakaszain a betegszervezetek képviselői is részt vettek. A folyamatos kapcsolattartás mellett mindössze két alkalommal volt szükség hivatalos tárgyalásra, a jogi háttér és a feltételek nem okoztak különösebb nehézséget.

Fontos megjegyezni, hogy még a hivatalos tárgyalások felvétele előtt sikerült a bécsi centrummal egy speciális szerződést (úgynevezett twinning agreement formájában) kötni a sürgôs májátültetések megvalósítása érdekében. Ennek lényege az volt, hogy amennyiben Magyarországnak ilyen életmentő beavatkozásra volt szüksége, a beteget felvették az Eurotransplant-várólistára, mintha bécsi beteg lenne, így aztán az évi akkori körülbelül 40 alkalmas magyar májdonor helyett az Eurotransplant évi mintegy 2000 donora állhatott rendelkezésre. Ilyenkor körülbelül 48 óránk van, hogy egy új májjal megmenthessük a beteg életét, ami a magyar donorokkal csaknem lehetetlen helyzet volt, hogy méretben és vércsoportban egyező szerv álljon rendelkezésre ilyen rövid időn belül. Ellenben az Eurotransplant segítségével így a csatlakozás előtt összesen 9 beteg életét tudtuk megmenteni. Az egyezmény ránk vonatkozó része az volt, hogy a következó magyar vércsoportazonos donormájat az Eurotransplantnak visszajuttassuk, amit mindig pontosan teljesítettünk.

\section{Az elôzetes csatlakozás}

2012 januárjában megtörténhetett az előzetes csatlakozás, amikor a gyermekek, a sürgős szervre várók és az immunizált betegek már Eurotransplant-várólistára kerülhettek, cserében Magyarország minden donort jelentett Leidennek. Az előzetes csatlakozással a sürgősségi átültetések megoldása automatikussá vált nemcsak a máj-, hanem a szívtranszplantáció vonatkozásában is, ami szinte azonnal jelentősen fellendítette a szívátültetések számát hazánkban.

A vesebeteg gyermekek múvesekezelés alatt nem növekednek, elmaradnak fizikai és szellemi fejlődésükben, nagyon fontos tehát, hogy minél hamarabb vesét kaphassanak. Sajnos nem mindig lehetséges élődonoros átültetés, a donorszerv mérete és életkora is nagyon fontos tényező. 2012-2013 során 25 átültetés történt az előző két év 14 beavatkozásához képest 15 év alatti gyermekeken, ami az Eurotransplant nélkül nem történhetett volna meg; ezzel gyakorlatilag majdnem kiürült a gyermekvese-várólista, és jelentősen csökkent a dializált gyerekek aránya.

Az immunológiailag érzékenyített betegek, akik majdnem minden donorral szemben pozitív keresztpróbát mutatnak, ezért nagyon kicsi valószínúséggel transzplantálhatók, szintén új reményt kaptak már az előzetes csatlakozással. Volt olyan beteg, aki 20 év(!) múvesekezelés és számos pozitív keresztpróba után kapott az Eurotransplantból vesét, és ment haza a klinikánkról jól múködő vesével. Az ilyen szakmai sikerek fokozatosan mindegyik magyar központban mindennapossá válhattak. A gyermek-szívtranszplantációs program is nagy örömmel üdvözölte a csatlakozást, reálissá vált a várólistán lévő müszíves betegek időben történő átültetése.

Az egészségpolitika beváltotta ígéretét: szakmai kollégiumot kapott a transzplantáció, ez is fontos lépés volt a kijelölt úton; szakmai kollégiumi elnökként könnyebbé vált a jó értelemben vett lobbizás is. De a szakma is beváltotta ígéretét: a várólistákon a betegek száma a szakmai erőfeszítéseknek köszönhetően közel a kétszeresére emelkedett mind az öt szerv vonatkozásában, ezzel is közelebb kerültünk a várt tagsághoz. Ezek a betegek aztán a csatlakozás napján ingyen, regisztrációs díj nélkül kerülhettek a közös Eurotransplant-várólistára. 
Az e cikk szerzője által kezdeményezett, külföldi szakemberek bevonásával történt szakmai konferenciát követően komoly áttörést jelentett az a tény, hogy a HLAlabor áttért a lépból való tipizálásról a vérből való tipizálásra, ezzel szignifikánsan (8-12 órával!) csökkent a vese hidegischaemiás ideje hazánkban, és az Eurotransplant szerinti standard került ezzel bevezetésre [9]. A legnagyobb akadály a végleges dokumentum aláírása előtt a HLA-labor nemzetközi akkreditációja volt, ami különböző okok miatt elhúzódott, ezért az előzetes csatlakozás után végül másfél évvel sikerült a végleges csatlakozás, 2013. július 1-jétől.

\section{A teljes jogú Eurotransplant-tagság}

Budapesten ünnepélyes keretek között került sor az aláírásra Balog Zoltán miniszter és Szócska Miklós államtitkár jelenlétében: Miskovits Eszter OVSZ-főigazgató magyar részről, Bruno Meiser elnök és Ferdinand Mühlbacher alelnök pedig az Eurotransplant részéról jegyezték a dokumentumot. A sikerhez három tényezónek kellett összeállnia: a szakmai szervezetek példás egysége, az egészségpolitika támogatása és az Eurotransplant befogadókészsége együttesen jelenthette a megoldást.

Az előzetes csatlakozással kezdődött negyedik jelentős korszak teljesen más dimenzióba helyezte a magyarországi szervátültetést. Innentől minden magyar betegnek az Eurotransplant-tagországokéhoz hasonló esélye lett transzplantáció vonatkozásában [10].

Az objektív számok tükrében (1. táblázat) [11] kiválóan nyomon követhető ez a folyamat. Egy tízéves periódust vizsgálva megállapíthatjuk, hogy némi ingadozással, de egyértelmû trendek figyelhetők meg. Az első lépés az élődonoros vesetranszplantációk abszolút számának megduplázódása volt, ez elsősorban a budapesti intézet érdeme [12]. Sajnos a vizsgált időszak végére ez valamelyest visszaesett. A csatlakozás folyamatával a donoraktivitás is jelentősen emelkedett, és ezzel párhuzamosan a többszervi donorok aránya hatalmas mérték- ben, a korábbi 40\%-os arányról 70\% fölé nőtt. A szívtranszplantációk számának szignifikáns emelkedése már egyértelmúen a csatlakozáshoz köthető, először az akut átültetések révén, majd az összes mútét számában is. A hasnyálmirigy-átültetések is örömteljesen megemelkedtek, de a periódus végére itt is visszaesés tapasztalható. A májtranszplantációk számának örvendetes emelkedése is egyértelmúen a csatlakozás hozadéka. Lang György és mtsai páratlan erőfeszítéseinek következtében a korábban Bécsben, magyar szervekkel végzett tüdőátültetések 2015-tól immáron szintén Budapesten történnek [13]. Bécsben 2017-ben már csak egy beteget transzplantáltak. Mindezek összesen azt eredményezték, hogy az összes magyarországi transzplantációk száma mintegy 40\%-kal(!) emelkedett a vizsgált időszakban, egyértelmúen az Eurotransplant-csatlakozás eredményeként. Ez volt az az arkhimédészi pont, amely kimozdította a holtpontról a szakma helyzetét egy olyan nehéz időszakban, amikor az egészségügy egyébként komoly válsághelyzetet ér meg; ez is csak a döntés helyességét húzza alá.

\section{További kihívások}

Bár a helyzet sokkal jobb a számok alapján, mint korábban volt, azonban még számos nehézség van, és szakmai kihívások sora, mert számos szempontból még mindig messze vagyunk attól, ami ma elérhető lenne, ha a legjobb mutatókkal rendelkező országokat vesszük alapul, márpedig csak ez lehet az összehasonlítási alap.

A gyermektranszplantációk szerencsére ritkán alkalmazott eljárások, de akkor szinte mindig nagy jelentőséggel bírnak a hosszú távú konzekvenciák miatt. Ahhoz, hogy a társadalom teljes jogú és ne hátrányos helyzetű tagja lehessen egy halálosan beteg gyerek, igen komoly szakmai összefogás szükséges. Ez leginkább a vese és a szív vonatkozásában van megoldva, a májtranszplantáció Magyarországon csak a nagyobb gyerekeknél lehetséges; egyelőre külföldön kerül sor a csecsemók és kisgyerekek

1. táblázat | Szervdonációs és transzplantációs adatok Magyarországon, 2008-2017

\begin{tabular}{|c|c|c|c|c|c|c|c|c|c|}
\hline Év & Donorszám & $\begin{array}{c}\text { Többszervi } \\
\text { donor }\end{array}$ & Összes vese & Élődonoros vese & Máj & Hasnyálmirigy & Szív & Tüdő & Összes \\
\hline 2008 & 148 & $41 \%$ & 259 & $24(10,2 \%)$ & 36 & 4 & 22 & 0 & 321 \\
\hline 2009 & 140 & $43 \%$ & 274 & $24(8,8 \%)$ & 40 & 9 & 24 & 0 & 347 \\
\hline 2010 & 159 & $43 \%$ & 307 & $42(13,7 \%)$ & 43 & 9 & 20 & 0 & 379 \\
\hline 2011 & 133 & $39 \%$ & 251 & $47(18,7 \%)$ & 41 & 10 & 14 & 0 & 316 \\
\hline 2012 & 143 & $52 \%$ & 276 & $53(19,2 \%)$ & 41 & 6 & 33 & 0 & 356 \\
\hline 2013 & 155 & $67 \%$ & 291 & $40(13,7 \%)$ & 45 & 14 & 45 & 0 & 395 \\
\hline 2014 & 203 & $70 \%$ & 387 & $48(12,4 \%)$ & 75 & 14 & 58 & 0 & 534 \\
\hline 2015 & 236 & $74 \%$ & 343 & $40(11,6 \%)$ & 89 & 13 & 51 & 1 & 497 \\
\hline 2016 & 182 & $70 \%$ & 342 & $34(9,9 \%)$ & 81 & 6 & 58 & 17 & 504 \\
\hline 2017 & 159 & $69 \%$ & 297 & $40(13,4 \%)$ & 74 & 6 & 52 & 21 & 450 \\
\hline
\end{tabular}


szervátültetésére, ideje lenne a tüdőtranszplantációhoz hasonlóan ezt is hazahozni.

Ma már a vércsoportkülönbségek ellenére is lehet élődonoros veseátültetést végezni, ennek sem a finanszírozása, sem az immunológiai háttere nincs megoldva jelenleg.

Nagy szervezési kihívást jelent a keresztdonáció, melynek bár a törvényi háttere lassan öt éve biztosított, mégsem került rá még sor.

Bár a májátültetések száma örvendetesen nőtt, jelentősen visszaesett a budapesti központban mind az élődonoros, mind a kadávervese-átültetések száma az utóbbi években.

Ritkán, de szükség lehet kombinált szív-máj, szív-tüdő, illetve máj-tüdő átültetésre: erre sem volt még példa, nagyon komoly interdiszciplináris kihívást jelent, a jelenlegi feltételek nem igazán adottak ezekhez.

A fejlett transzplantációval rendelkező országokban az úgynevezett „nem dobogó szívű donorok” (elsősorban veseátültetése) rutinbeavatkozásnak számít. Magyarországon törvényi szabályozást kellene változtatni ahhoz, hogy ez elérhető legyen, és ezzel a lehetőséggel bővülhessen az átültethető szervek száma.

A transzplantációs szakma minden szinten nagy leterhelést jelent a 7/24-es rendszerével (7 nap és 24 órában kell rendelkezésre állni a teameknek szervkivételre és -betételre). A mai egészségügyi környezetben ez egyre nehezebben oldható meg. Hogy mégis radikális előrelépés történt ezen a szakmai területen, az az ebben részt vevők áldozatkészségének köszönhető; ennek haszonélvezői a betegeink, akik új élet esélyét kapják azzal, hogy adott esetben például egy éjszaka körülbelül 100 diplomás és legalább ekkora létszámú kisegítő személyzet dolgozik egyetlen sikeres szervátültetés érdekében, ami általában két helyszínen (esetleg két országban) jelent hosszú órákig tartó mütéteket.

Az Eurotransplant professzionális szervezettsége volt a garancia arra, hogy ez immár több mint öt éve megvalósulhasson. Az aláírási ünnepségen Langer professzor úgy fogalmazott, hogy ünnep ez a magyar transzplantáció számára, melynek gyümölcseit azóta is nap mint nap learathatjuk a betegek minőségi élethez juttatásával.

Anyagi támogatás: A közlemény megírása anyagi támogatásban nem részesült.
A szerző a cikk végleges változatát elolvasta és jóváhagyta.

Érdekeltségek: A szerzőnek nincsenek érdekeltségei.

\section{Irodalom}

[1] Németh A, Petri G, Gál G, et al. Kidney homotransplantation in 2 brothers. [Vese-homotransplantatio két testvér között.] Orv Hetil. 1963; 104: 2017-2023. [Hungarian]

[2] Csajbók E. First steps of the national organ transplant program (In memoriam András Németh). [A hazai szervátültetések kezdeteiről - In memoriam Németh András]. Orvosképzés 2011; 86: 45-48. [Hungarian]

[3] Perner F, Megyaszai S, Járay J, et al. Successful kidney transplantation in Hungary. [Sikeres veseátültetés hazánkban.] Orv Hetil. 1974; 115: 2067-2068. [Hungarian]

[4] Langer RM, Perner F. Transplantation in Hungary - Preface on the Occasion of Transplantation Proceedings Becoming the Official Journal of the Hungarian Transplantation Society. Transplant Proc. 2010; 42: 2279-2280.

[5] Langer RM, Cohen B, Rahmel A. History of Eurotransplant. Transplant Proc. 2012; 44: 2130-2131.

[6] Mebel M, May G, Althaus P. Der komplette Nierenersatz!? Aufbau und Entwicklung der Nierentransplantation in der DDR. Pabst Science Publishers, Lengerich, 2003; pp. 95-102.

[7] http://hvg.hu/hetilap.tarsadalom/200640HVGFriss223 [accessed: June 15, 2018]. [Hungarian]

[8] Langer R. Eurotransplant - a new possibility for the Hungarian transplantation. [Eurotransplant - új lehetőség a magyar transzplantáció számára.] Orv Hetil. 2011; 152: 243-245. [Hungarian]

[9] Inotai D, Boros-Major A, Illés Z, et al. Decrease in cold ischemic times as a result of protocol changes of urgent immunogenetic testing during cadaveric kidney transplantation in Hungary. Transplant Proc. 2012; 44: 2132-2135.

[10] Langer R. Milestone in Hungarian organ transplantation: joining Eurotransplant. [Mérföldkő a magyar szervátültetésben: csatlakozás az Eurotransplanthoz.] Orv Hetil. 2013; 154: 844-845. [Hungarian]

[11] http://www.ovsz.hu/oco/donacios-transzplantacios-alapadatok-2017 [accessed: June 15, 2018]. [Hungarian]

[12] Bäcker H, Piros L, Langer RM. Increasing living donor kidney transplantation in Budapest. Transplant Proc. 2013; 45: 36783681 .

[13] Rényi-Vámos F, Radeczky P, Gieszer B, et al. Launching the Hungarian Lung Transplantation Program. Transplant Proc. 2017; 49: 1535-1537.
(Langer Róbert dr., Fadingerstrasse 1., A-4020 Linz e-mail: roblanger@hotmail.com) 